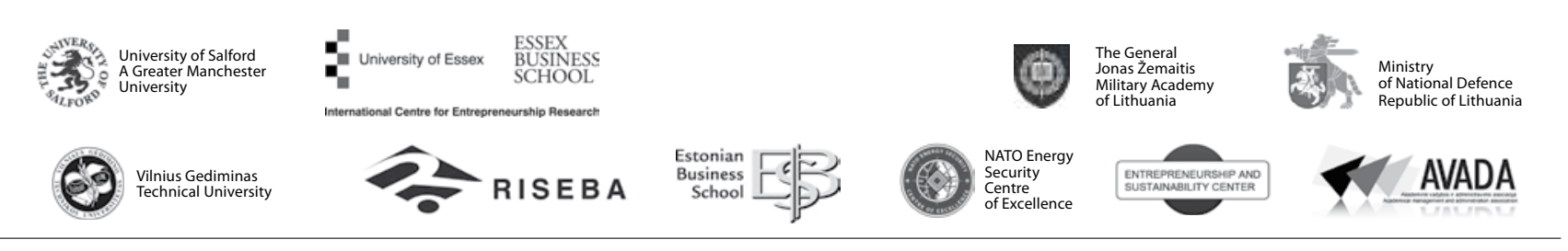

\author{
JOURNAL OF SECURITY AND SUSTAINABILITY ISSUES \\ ISSN 2029-7017 print/ISSN 2029-7025 online \\ 2018 September Volume 8 Number 1 \\ https://doi.org/10.9770/jssi.2018.8.1(10)
}

\title{
THREATS TO THE COUNTRY'S SUSTAINABLE ECONOMIC DEVELOPMENT: A CASE STUDY
}

\author{
Joana Katina ${ }^{1}$, Galiya Nurymovna Sansyzbayeva ${ }^{2}$, Aida Guliyeva ${ }^{3}$, Ulviyya Rzayeva ${ }^{4}$ \\ ${ }^{1}$ Vilnius University, Institute of Informatics, Didlaukio 47, LT-08303 Vilnius, Lithuania \\ ${ }^{2}$ University of the International Business, Kazakhstan \\ ${ }^{3,4}$ Azerbaijan State University of Economics, Istiqlaliyyat str. 6, AZ 1000, Baku, Azerbaijan
}

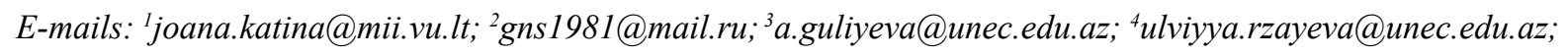

Received 15 May 2018; accepted 27 July 2018

\begin{abstract}
Our paper focuses on the threats to the global development and sustainable economic development of a country that might include economic, political, human development, as well as sustainable development issues and problems. Sustainable economic development might serve as a tool for fostering the country's prosperity and helping it to overcome various threats that might stem from its geolocation, economic situation, natural resources, as well as many other internal and external factors that all play their decisive roles. The paper uses a case study of the United States as an example of the country vulnerable to a plethora of threats. It analyzes the most crucial threats one by one and classifies the most notorious and impending issues stemming from these threats that might hamper the economic growth and development. In particular, we focus on the issue of energy security and the renewable energy sources (RES) that represent an important aspect in this debate and research. Our results can be used by the policymakers as well as regional development managers for improving the security strategy.
\end{abstract}

Keywords: sustainability, economic development, political development, human development, threats, United States

Reference to this paper should be made as follows: Katina, J.; Sansyzbayeva, G. N.; Guliyeva, A.; Rzayeva, U. (2018). Threats to the country's sustainable economic development: a case study, Journal of Security and Sustainability Issues 8(1): 113-122.

https://doi.org/10.9770/jssi.2018.8.1(10).

JEL Classifications: FO2; O11; O19; P10

\section{Introduction}

Global development has been the focus of governments, international organizations, and other stakeholders across the world. However, despite the fact that there has been increased focus on national and international development, there still are challenges to the attainment of the desired development goals and objectives. In 2000, the different states of the United States ratified and collectively agreed to work towards the realization of the eight millennium development goals (MDGs); eradicate poverty, achieve universal primary education, promote gender equality, reduce child mortality, improve maternal health, combat HIV/AIDS, malaria, and other disease, foster environmental sustainability, and develop global partnerships to support the achievement of these goals by the year 2015 (Stojanov et al. 2011; Sachs 2012; Niño-Amézquita et al. 2017). The lapse of the period was followed by the ratification and commitment to work towards the sustainable development goals (SDGs) starting from 2015, which according to Hák et al. (2016), are designed as a furtherance of the MDGs general agenda.

A scrutiny of the MDGs and the SDGs shows that the concept of development as constructed and used currently, goes over and above economic development to encompass other factors. According to Hill and Hult (2017), conventionally, development was assessed premised on specific economic statistics, such as gross do- 
mestic product (GDP) and Gross National Income (GNI), but premised on the works of Kelley, development is now measured using somewhat wider criteria, the Human Development Index, that measures development on the basis of economic and other factors such as living standards, health, and human capability. Premised on the more holistic criteria for measuring development, it is possible for governments to formulate and implement policies that foster general or more holistic development. It is in the context of the widened scope of understanding of development, that this report will assess the key challenges that hinder development in specific developed and developing countries, such as the United States, China, Britain, and Haiti.

This paper focuses on the analysis of the threats to the sustainable economic development using a case study of the United States. It is organized as follows: Section 2 provides a comprehensive literature review. Section 3 provides a case study of the United States and scrutinizes the threats for its sustainable economic development stemming from the economic, political, as well as geopolitical factors. Section 4 provides discussions of the results. Section 5 concludes with some closing remarks and policy implications.

\section{Literature review}

As enumerated in the introduction, the scope of defining, assessing, and measuring development has expanded to include additional elements, in the human development index, over and above the conventional economic indicators that have been previously widely used. According to the United Nations Development Program (UNDP 2018), the human development index (HDI), in addition to economic indicators, includes different other factors, such as life expectancy, measured by life expectancy index; knowledge, measured by education index; and economic factors which indicate premised on the specific economic indicators, GNI and GDP among others, countries are ranked as either developed or developing countries, which will have or experience different types of challenges to development, depending on the country's ranking and current performance and actions towards fostering development. Accordingly, considering that the HDI criterion is wider, the challenges that impede development, assessed from this perspective, in the different countries, will be more. The factors that could hinder development, when development is considered from a HDI perspective, can be categorized as political, economic, environmental or natural, and social factors, which in turn have implications on the other areas of an economy, and subsequently, development (Kalyugina et al. 2015; Vasylchak and Halachenko 2016; Cardoso et al., 2018; Rocha, Neves 2018; Ivanova, Latyshov 2018; Muniz et al. 2018; Monni et al. 2018; Mikhaylov 2018).

Political factors are quite broad, encompassing different aspects of the political administration of a According to Pye and Verba (2015), the politics of a country, and by extension, the administration and the ensuing policies formulated and implemented by each regime, to a large extent, have an impact on the other aspects of the society, such as economic, and social aspects of the society. In agreement, Acemoglu and Robinson (2006) opined that the political systems of a country, which determine the competition for and allocation and utilization of resources, have a greater impact on the other aspects of a country, and will therefore influence the realization of the development goals and objectives of a country. Considered in the context of international development, political factors would be understood from the perspective of increased competition between different countries in the clamor for supremacy in the global hegemonic order.

Evidently, political factors, as a hindrance to the attainment or realization of development goals, is very wide because it encompasses a wide range of factors, looking at it internally, within a country, it will include aspects such as the form of government, which could be autocratic or democratic, with commensurate effects on the attainment of the development agendas. As Escribà-Folch (2013) observes, normally, democratic political regimes provide a favourable environment for the pursuit and realization of development goals, while autocratic regimes are characterized by plunder and self-enrichment. As Koudelková et al. (2015) show, corruption might become a large and considerable obstacle within this context. From this perspective, it is evident that democracy supports development while autocracy is detrimental to the pursuit of human development, such as the eradication of poverty. For countries such as the United States and Britain, the political systems in place, mainly democratic, have fostered the attainment of development from a HDI perspective, whereas for a country like 
China, with a weaker democracy, even though economic development is being realized, holistic development from a HDI perspective has not been achieved.

In addition, political factors influence other aspects of development from the HDI perspective such as education policies, social policies, and economic policies, demonstrating the far-reaching effects of political factors on the attainment of national and international development goals and objectives. Indeed, according to Johnston (2000), government policies, and specific actions, foster or restrict the attainment of development goals, such as policies, laws, and regulations for fighting corruption will promote development, whereas in a country where democracy prevails but there are not adequate measures to fight the vice, development will be curtailed. According to Acemoglu and Robinson (2006) government policies, an offshoot of the political systems in place will have far reaching effects in different spheres of the society that will affect or determine the levels of development achieved by a country. As such, apart from ensuring a favorable environment for development by ensuring stability and promoting the rights of the majority and equality, politics will also have an impact on the economic performance of a country.

Within the HDI as enumerated above, the standards of living, measured using the GNI index, is an important indicator of development (UNDP 2018). Indeed, according to Sachs (2012) a key component of development, as contained in the MDGs and in the SDGs, is eradication of poverty to promote decent working and living conditions for the populations. Economic instability will therefore be a major impediment to the attainment of development goals and objectives. According to Hák et al. (2016), unemployment rates, financial crisis and recession as was the case in 2008/2009, and economic disparities and inequalities are some of the key economic elements that are an impediment to the attainment of development goals and objectives in countries.

From this perspective, the United States, Britain, and China, as well as a developing country, such as Haiti, where the gap between the rich and the poor is continuously growing, there is a hindrance to the attainment of development goals and objectives. However, in developed countries, such as United States and Britain, where unemployment rates and poverty rates are lower, the extent of economic factors as an impediment to development, compared to developing countries such as Haiti, is not as extensive (Balaam and Dillman 2015). Other aspect of economic factors are trade and economic practices, such as protectionism and international trade conflicts, which are not in the spirit of global partnerships as envisioned as promoters of development in SDGs and MDGs, across countries ranked as developed or developing countries. As such, the extent to which economic factors promote or impede development from a HDI perspective will be limited in developing countries, compared to developed countries. However, while economic and political factors are very important, social and environmental factors will pose similar challenges. Other factors that are an impediment to the attainment of development goals and objectives are social and environmental factors that crate the basis of the sustainable development strategy, especially in the national energy strategy (see e.g. Balitskiy et al. 2014; Lisin et al. 2015; Lisin et al. 2016; Streimikiene et al. 2016; or Strielkowski and Lisin 2017; Tvaronavičienė 2018a; 2018b; Plenkina et al. 2018; Tvaronavičienè et al. 2018).

Social factors, according to Hill and Hult (2017) include factors such as demographic changes, and global and country-specific population growth, which have implications for international trade, and by extension growth and development. The global population, including in the United States, Britain, China, and other countries, such as Haiti, is continuously growing placing pressure on the environment because of increased competition for resources, posing a major impediment to development from different perspectives (Dell'Angelo et al. 2017). As such, social changes, such as enumerated above, population growth, will put pressure on the environment, which leads to environmental pollution and degradation, which contravenes the SDGs and MDGs as well as the HDI.

From another perspective, the environment, as a stand-alone factor, has different dimensions, one being resources endowment, and the other being natural disasters. In terms of resources endowment, the availability and use of natural resources, or lack of the same, could promote or hinder development, which is quite evident in the United States, Britain, and China, which have been well endowed with different environmental resources 
but the depletion of the same, such as petroleum and other minerals, is threatening sustainable development (Nellemann et al. 2014). On the other hand, environmental calamities, such as cyclones, extended winters, and global warming, ensuing from human activities, and natural disasters, such as the recent volcanic activities in Haiti, collectively hinder or impede the realization of development goals and objectives.

\section{Threats to a country: a case study of the United States}

The United States of America is undoubtedly the most powerful country in the world. However, the beginning of 21 st Century has seen the country witness myriads of challenges and threats. The challenges are basically economic and political. However, there are other aspects of challenges related to social issues. But, political and economic threats are the main concern as they pose serious risks to the most powerful economy and democracy (Seoergel 2018). The emergence of China as an economic powerhouse and the insurgence of terrorism has seen America concerned and worry about the impending doom as some would call it. First, on the social and political domain, it is important to indicate that America is increasingly becoming a divided nation. Trump's presidency has done little to reduce the widening gap between race, class and religion not to mention other social groupings such as LGBT. The politics of the country has changed, and polarization continues to rock the nation. On the global level, America is under threat of terrorism. The terror groups such as Isis and Taliban continue to pose a huge risk to the security of the nation (Seoergel 2018). Moreover, the emergence of China as a superpower and its alliance with American adversaries such as Russia and North Korea only makes the equation more complicated for the nation. It is the right to argue that America is under intense threat both in terms of economic and political aspect. It is on this basis that this paper seeks to analyse the political and economic threats to the United States of America.

\subsection{Economic threat to the United States}

\section{Public Debts}

The rising public debt is one of the main threats to US economy. The inability of the federal government to keep its spending under control has only led to the pilling of the public debt. The uncontrolled spending has led to enormous debt burden by the government. It is estimated that investors outside the United States have funded a quarter of the debt which is around $\$ 1.9$ trillion (Bachmann \& Gunneriusson 2013). The accrual of debts by the government caused by the deficit spending is a tax shift to future generation from the current generation. The same is true when the funds are used for the operational expenses that are used to finance public projects and operations. From the given information, it is evident that if the accruing debts are not controlled, then the future generations will likely suffer the consequences of the tax burned. The same will likely affect trade and investments as a huge portion of the revenue will be used to service the accruing debts.

\section{Overseas military operations and trade war with the EU and China}

There have been debates on whether or not China poses an economic threat to the United States. The truth is that China is indeed a threat to the US, especially with respect to economics. For a long time, the USA has remained world's largest economy (Bachmann and Gunneriusson 2013). More than 140 years down the line, the United States has remained the largest economy, but things are changing with China emerging as the second largest economy and with the highest purchasing power. The country has overtaken the United States at least with respect to one dimension, and that is GDP based on the purchasing power parity. For example, in 2012/2013, the GDP growth rate of China was ahead of that of the United States. China also had around \$1.5 trillion more than the US. Not to mention that China is a huge state with a population that is around five time that of the United States. The constant involvement in Wars on terror is also eating into the nation's resources making it weaker with time.

Population power is another aspect of threat that China poses to the United States with regard to economy. 
According to 2013 population census, China population is 1.357 Billion while that of US is just 318.9 million (Ciuriak et al. 2017). The given disparity is an advantage to China, because in the event that the two countries come neck to neck, then China will not be easy to conquer. The huge population also means that China has an enormous purchasing power. The population is the same reason why India has left Pakistan and is inclining towards India because it can match China easily in terms of population (Sikuta 2008). The US considers India as the best tool to be used against China. However, the highlighted claim is anecdotal and is subject to debate and interpretation.

Finally, the veto power and the Russian support is another interesting aspect of economic threat that China poses to the United States. It is important to indicate that China, just like the United States has the veto power. The nation can use this power to influence its region or any other place in the world (Sikuta 2008). The given situation is a huge concern to the US as it promotes Chinese stakes in at the global level not just with the United Nations but also with the rest of the world. Chinese influence is rapidly growing considering their political manoeuvres and especially their alliance with Russia. China shares a huge border with Russia and has consistently supported it on many occasions. For example, the Chinese have always supported Russians actions against Ukraine urging the West to consider Russia's security concerns over Ukraine. Moreover, the Chinese have been willing and ready to conduct business with the Russians. For example, in 2012, the Chinese foreign minister Wang Yi said that China was ready and willing to offer loans to initiate the building of the new Russia-China gas pipeline, and it is evident that China does not want to see the economic collapse of Russia.

\section{Brexit as an economic threat to the USA}

The departure of Britain from the European Union will definitely send shock waves to the economy of the United States given that the two are long-term allies. The United States is a critical ally and trade partner of the Britain (Ciuriak et al. 2017). For that reason, a massive political action by the Britain must have an impact on the U.S economy both as a political ally as well as a trade partner. It is right to argue that the consequences of Brexit will have a negative impact on the economy of the United States to a huge extent. The same is mirrored by the ongoing uncertainty with respect to the terms of Brexit. The Britain policymakers are divided on whether to adopt 'hard' or 'soft' Brexit either of which is likely going to affect not just the United States but also the rest of Europe and the world in general. Policy makers believe that Brexit is the largest and immediate risk that faces financial markets both locally and globally, especially with regard to migration (like many times before) (Strielkowski and Weyskrabova 2014). The tremor that was caused by the Britain's exit was felt not just by the United Kingdom but also by other countries and nations such as the United States of America. From the given analysis, it is evident that the Brexit will likely have a considerable impact (possibly negative) on the global economy and these are some of the risks and dangers that the United States is also likely to face both in the short run as well as in the long run.

\subsection{Political Threat to the United States}

\section{The threat to America's Democracy through internal divisions}

The massive internal division of the American society continues to threaten its unity as a democracy. Violence against lawmakers, inaccessibility of the white house by the press and the apparent ease with which the Russians influenced America's elections only proves that its democracy is at risk (Barber, 2017). The deep political division and distrust of the government are only widening the rift between opposing factions of the American society. It is for that reason apparent that the ethnic division and xenophobic behaviour promoted by the farright wing politics will only worsen the situation. 
The emergence of China as a political force with nuclear power is a massive threat to the United States considering its alliance with Russia and North Korea. Since the last round of UN sanctions, North Korea has issued threats to the United States, and policymakers believe that the threats of North Korea to the United States is potent. North Korea has always threated South Korea, a key ally of the United States in the region. For example, in 1994 South Koreans panicked after a threat by the North Korea to turn Seoul into a "Sea of fire". The same threat has been repeated several times, and in 2012, the army warned that artillery was aimed at the seven South Korean media groups, and they were threatened by a merciless massacre. In recent years, North Korea has consistently warned a pre-emptive nuclear attack on the US soil in response to a prospect of joint military exercise between the South and US (Barber, 2017). The tension imposed by North Korea and the possible attack on the United States is viewed as an issue that threatens the cohesion and even the future of the nation.

However, to confirm whether or not the United States is a real target of North Korea's threat, a test was carried out on the fragments of the rockets that were fired in December 2012, and it indicated that it had a range of $10,000 \mathrm{~km}$ and hence putting the United States within the range. It is the evidence that North Korea is a real threat to the United States both politically and in terms of security (Reynolds 2002). However, apart from North Korea, the United States also has Russia and China to worry about, and this makes it hard for the country to concentrate in alleviating one particular threat (Haytko et al. 2018). Furthermore, its continual involvement in the endless wars only makes it impossible to recover and in time both financially as well as politically (Reynolds 2002). Finally, from the analysis of the economic and political threats to the United States, it is evident that internal divisions and the emergence of nuclear powers are key political threats (Ahn 2011). On the other, in terms of economic, the rising public debt and the rise of China as economic power poses a huge challenge to the dominance of the United States as economic and world power. More needs to be done for the nation to maintain its position as the world's most powerful country in terms of economics and politics.

\subsection{Energy and energy policy threats to the United States}

Finally, the last but not the least important threat to the country's economic and political security is the issue of energy and energy policy threats. United States is a vast and diverse country with a large consumption of energy. It has been estimated that if everyone on planet Earth had the same consumption patterns as an average U.S. citizen, the humankind would have needed at least 5 planets like the one it dwells upon (McDonald 2015). Thence, in spite of U.S. large oil and gas resources, its energy consumption patterns constitute its big threat.

These trends have not stayed unnoticed by the U.S. government. In February 2009, in his speech at the Congress U.S. President Barack Obama called for doubling renewable energy within the following three years. The progress in the renewable energy has been apparent ever since. Currently, renewable energy accounts for about $20 \%$ of total electricity production in the United States with such sources as hydro, wind and solar rising (see Figure 1). 


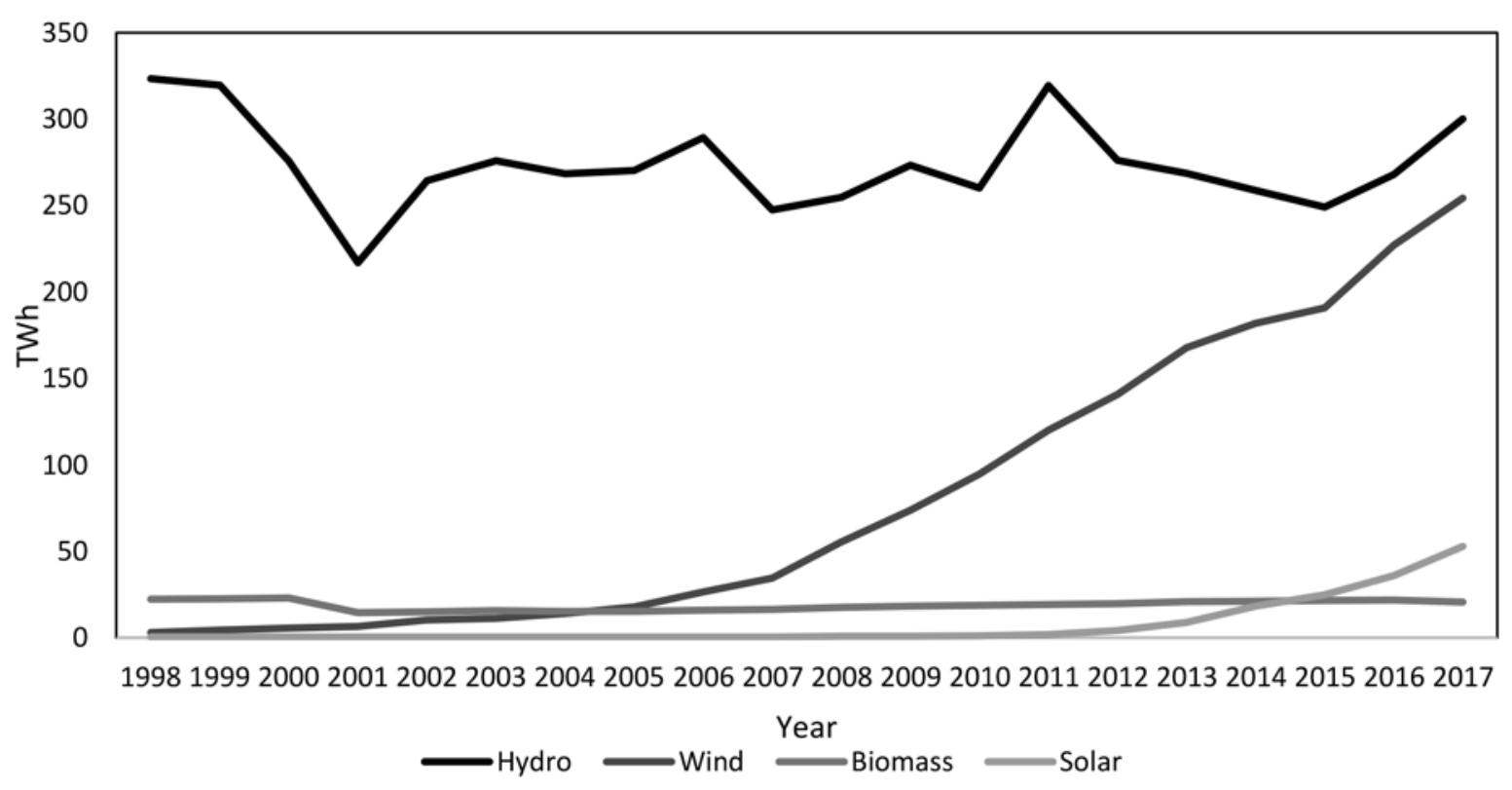

Fig. 1. Renewable energy production by source in the United States (TWh)

Source: U.S. Energy Information Administration (2018)

However, the new presidents Donald Trump has shifted the U.S. energy focus. Under his presidency, the country did not ratify the United Nations Framework Convention on Climate Change (UNFCCC) held in Paris on the 12th of December 2015 (so-called "Paris Agreement") (Strielkowski et al., 2016). This represents a very serious concern, since the Paris Agreement was especially initiated in order to find solutions to the impending climate policies and challenges faced by the key players, such as United States itself.

\section{Discussions and closing remarks}

A wide range of factors, as enumerated in above, pose a threat to the attainment of development goals and objectives, in the context of development as defined under the human development index perspective. Political impediments are multidimensional, encompassing the political system, political decisions, energy strategies, and administrative policies (Balaam and Dillman 2015). As such, as a system of government, democracy in United Kingdom and United States support development but some policies, with roots in political element, are detrimental to development, such as Britain's exit from the European Union (Brexit), which could be an impediment to the collective development even though it may promote the interests of the particular country. Political competition and failures in creating and maintaining global partnerships for development in line with MDGs and SDGs as is evidenced by the continuous competition between the United States and China. This scenario gives rise to the economic factors that are an impediment to the achievement of development, including disparities, inequalities, poor economic policies, and restrictive trade practices which hinder development at the national and international levels.

Social factors on the other hand, as enumerated by Dell'Angelo et al. (2017) include all the factors, attributable to changes in the society that impede development, which from the HDI perspective encompass population growth and the ensuing pressures on the environmental resources. The global population growth, including rapid growth of the population in China, United States, and Britain, has resulted in a significant impact on the environment and the accompanying problems, such as global warming. Environmental factors, including environmental degradation, natural resources endowments, and natural calamities or disasters are the other impediments to the development, with countries that have been endowed, but nearing the depletion of environmental resources, such as the United States, Britain, and China, causing a major impediment to sustainable development because of the threats posed by the impeding threat of resources depletion (Hák et al. 2016). 
Last but not least, the impending climate changes, global warming and raising $\mathrm{CO}_{2}$ emissions also represent a threat and call for the modernization of energy policies and energy strategies. Renewable energy should be promoted in spite of its current higher per-unit costs. This is a political decision that needs to be done in order to ensure sustainable development and economic growth in the future volatile and changing world.

\section{Conclusions and implications}

Sustainable economic development, assessed from the human development index perspective, is more holistic and includes multiple indicators of development over and above the conventional economic indicators. As such, a wide range of factors pose a threat to sustainable development nationally and internationally, when development is considered from the HDI perspective. Political factors are multi-dimensional, encompassing political systems, stability, administration, and policies of the country, and the ensuing political competition between different countries. For example, democratic systems present an opportunity for development while autocratic systems may be a hindrance to development. Economic factors on the other hand, include different aspects of the national and international economy that hinder development in terms of fostering good living standards of the people. Social factors on the other hand, include demographic changes, such as population growth and the subsequent effect on the attainment of development, such as pressures on the environment as an impediment to development. Subsequently, the other factors are environmental factors, which are also multi-dimensional covering resources endowments or natural calamities as an impediment to development.

\section{Acknowledgments}

Project title - "Development of model of sustainable social and economic development in the context of implementation of the Concept on transition of the Republic of Kazakhstan to "green" economy"

\section{References}

Acemoglu, D.; Robinson, J. A. 2006. Economic backwardness in political perspective. American Political Science Review 100(1): 115131. https://doi.org/10.1017/S0003055406062046

Ahn, T. 2011. Politics at the Water's Edge: The Presidency, Congress, and US Policy toward North Korea. Pacific Focus 26(3): $336-359$. http://doi.org/10.1111/j.1976-5118.2011.01068.x

Bachmann, S.; Gunneriusson, H. 2013. Terrorism and Cyber Attacks as Hybrid Threats: Defining a Comprehensive Approach for Countering 21 st Century Threats to Global Risk and Security. SSRN Electronic Journal. http://doi.org/10.2139/ssrn.2252595

Balaam, D. N.; Dillman, B. 2015. Introduction to international political economy. Routledge.

Balitskiy, S.:, Bilan, Y.; Strielkowski, W. 2014. Energy security and economic growth in the European Union. Journal of Security \& Sustainability Issues 4(2): 125-132. https://doi.org/10.9770/jssi.2014.4.2(2)

Barber, S. 2017. The Brexit environment demands that deliberative democracy meets inclusive growth. Local Economy 32(3): 219-239. https://doi.org/10.1177/0269094217705360

Cardoso, P. P.; Swan, A.; Mendes, R. 2018. Exploring the key issues and stakeholders associated with the application of rainwater systems within the Amazon Region, Entrepreneurship and Sustainability Issues5(4): 724-735. https://doi.org/10.9770/jesi.2018.5.4(2)

Ciuriak, D.; Dadkhah, A.; Xiao, J. 2017. Brexit Trade Impacts: Alternative Scenarios. SSRN Electronic Journal. http://doi.org/10.2139/ ssrn. 2981314

Dell'Angelo, J.; D’Odorico, P.; Rulli, M. C. 2017. Threats to sustainable development posed by land and water grabbing. Current Opinion in Environmental Sustainability, 26, 120-128. https://doi.org/10.1016/j.cosust.2017.07.007

Escribà-Folch, A. 2013. Repression, political threats, and survival under autocracy. International Political Science Review 34(5): 543560. https://doi.org/10.1177/0192512113488259

Hák, T.; Janoušková, S.; Moldan, B. 2016. Sustainable Development Goals: A need for relevant indicators. Ecological Indicators 60: 565-573. https://doi.org/10.1016/j.ecolind.2015.08.003 
Haytko, D. L.; Clark, R. A.; Hermans, C. M.; Parker, R. S. 2018. Examining the Dimensionality in Global Attitudes Toward Advertising: A Comparison of Perceptions of Chinese and United States Consumers. Journal of International Consumer Marketing 30(2):85-97. https://doi.org/10.1080/08961530.2017.1376603

Hill, C. W. L.; Hult, T. M. 2017. International Business: Competing in the Global Marketplace (11 ${ }^{\text {th }}$ ed). New York, NY: McGraw Hill. Ivanova, S.; Latyshov, A. 2018. Sustainable entrepreneurship: agrarian policy in South Korea, Entrepreneurship and Sustainability Issues 5(4): 748-760. https://doi.org/10.9770/jesi.2018.5.4(4)

Johnston, M. 2000. Corruption and Democracy: Threats to Development, Opportunities for Reform. Department of Political Science, Colgate University.

Kalyugina, S.; Strielkowski, W.; Ushvitsky, L.; Astachova, E. 2015. Sustainable and secure development: facet of personal financial issues, Journal of Security \& Sustainability Issues 5(2): 297-304. http://doi.org/10.9770/jssi.2015.5.2(14)

Koudelková, P; Strielkowski, W.; Hejlová, D. 2015. Corruption and system change in the Czech Republic: Firm-level evidence. DANUBE: Law and Economics Review 6(1): 25-46. https://doi.org/10.1515/danb-2015-0002

Lisin, E.; Rogalev, A.; Strielkowski, W.; Komarov, I. 2015. Sustainable modernization of the Russian power utilities industry. Sustainability 7(9): 11378-11400. https://doi.org/10.3390/su70911378

Lisin, E.; Sobolev, A.; Strielkowski, W.; Garanin, I. 2016. Thermal efficiency of cogeneration units with multi-stage reheating for Russian municipal heating systems. Energies 9(4): 269. https://doi.org/10.3390/en9040269

McDonald, C. 2015. How many Earths do we need? BBC magazine. https://www.bbc.com/news/magazine-33133712

Mikhaylov, A. S. 2018. Socio-spatial dynamics, networks and modelling of regional milieu, Entrepreneurship and Sustainability Issues 5(4): 1020-1030. https://doi.org/10.9770/jesi.2018.5.4(22)

Monni, S.; Iorio, M.; Realini, A. 2018. Water as freedom in the Brazilian Amazon, Entrepreneurship and Sustainability Issues 5(4): 812-826. https://doi.org/10.9770/jesi.2018.5.4(8)

Muniz, J.; de Melo, M. d.; Liberato, M. A.; Wahnfried, I.; Vieira, G. 2018. Towards sustainability: allowance rights for using water resources in Amazonas State of Brazil, Entrepreneurship and Sustainability Issues 5(4): 761-779. https://doi.org/10.9770/jesi.2018.5.4(5)

Nellemann, C.; Henriksen, R.; Raxter, P.; Ash, N.; Mrema, E. 2014. The environmental crime crisis: threats to sustainable development from illegal exploitation and trade in wildlife and forest resources. United Nations Environment Programme

Niño-Amézquita, J.; Dubrovsky, V.; Jankurová, A. 2017. Innovations and competitiveness in regional development: a comparison of Latin America, Europe, and China, Czech Journal of Social Sciences, Business and Economics 6(1):28-36. http://doi.org/10.24984/ cjssbe.2017.6.1.4

Plenkina, V.; Andronova, I.; Deberdieva, E.; Lenkova, O.; Osinovskaya, I. 2018. Specifics of strategic managerial decisions-making in Russian oil companies, Entrepreneurship and Sustainability Issues 5(4): 858-874. https://doi.org/10.9770/jesi.2018.5.4(11)

Pye, L. W.; Verba, S. 2015. Political culture and political development. Princeton University Press.

Reynolds, B. 2002. Does economic reform improve US-China relations? China Economic Review 13(4): 402-406. http://doi.org/10.1016/ s1043-951x(02)00097-4

Rocha, G. d.; Neves, M. B. 2018. Hydroelectric projects and territorial governance in regions of The State of Pará, Brazilian Amazon, Entrepreneurship and Sustainability Issues 5(4): 712-723. https://doi.org/10.9770/jesi.2018.5.4(1)

Sachs, J. D. 2012. From millennium development goals to sustainable development goals. The Lancet 379(9832): 2206-2211. https:// doi.org/10.1016/S0140-6736(12)60685-0

Seoergel, A. 2018. China, Terrorism and Trump: The Top 10 Threats to the Global Economy. https://www.usnews.com/news/slideshows/china-terrorism-and-trump-the-top-10-threats-to-the-global-economy

Sikuta, J. 2008. Threats of Terrorism and the European Court of Human Rights. European Journal of Migration and Law 10(1): 1-10. http://doi.org/10.1163/138836407x261317

Stojanov, R.; Strielkowski, W.; Drbohlav, D. 2011. Labour migration and remittances: current trends in times of economic recession. Geografie 116(4): 375-400. 
Štreimikienè, D.; Strielkowski, W.; Bilan, Y.; Mikalauskas, I. 2016. Energy dependency and sustainable regional development in the Baltic States: A review. Geographica Pannonica, 20(2):79-87. https://doi.org/10.5937/GeoPan1602079S

Strielkowski, W.; Lisin, E. 2017. Economic Aspects of Innovations in Energy Storage. International Journal of Energy Economics and Policy 7(1):62-66.

Strielkowski, W.; Lisin, E.; Gryshova, I. 2016. Climate policy of the European Union: what to expect from the Paris agreement. Romanian Journal of European Affairs 16(4): 68-77.

Strielkowski, W.; Weyskrabova, B. 2014. Ukrainian Labour Migration and Remittances in the Czech Republic. Tijdschrift voor economische en sociale geografie 105(1):30-45. https://doi.org/10.1111/tesg.12052

Tvaronavičienè, M. 2018a. Towards sustainable and secure development: energy efficiency peculiarities in transport sector, Journal of Security and Sustainability Issues 7(4): 719-725. https://doi.org/10.9770/jssi.2018.7.4(9)

Tvaronavičienė, M., Prakapienė, D., Garškaitė-Milvydienė, K., Prakapas, R., Nawrot, Ł. (2018b). Energy Efficiency in the Long-Run in the Selected European Countries. Economics and Sociology, 11(1), 245-254. https://doi.org/10.14254/2071- 789X.2018/11-1/16

U.S. Energy Information Administration. 2018. Electric Power Statistics. https://www.eia.gov/electricity

UNDP. 2018. Human Development Index (HDI). http://hdr.undp.org/en/content/human-development-index-hdi

Vasylchak, S., Halachenko, A. 2016. Theoretical basis for the development of resort services: regional aspect. International Economics Letters 5(2):54-62. http://dx.doi.org/10.24984/iel.2016.5.2.3 